\title{
Commentary
}

\section{An Argument and an Outline for a New Employment Scheme}

\section{Henning Hansen}

Consultant in Analyse \& Tal/CASA, Denmark

\section{Jens Lind'}

Professor at Aalborg University, Denmark

\section{Iver Hornemann Møller}

Professor emeritus, CBS, Denmark

\section{DOI}

To be announced

\section{Introduction}

iberalism is celebrating triumphs in these years. As faith in the welfare state and Keynesianism began to crack in the 1970s, capitalist principles were revitalised and the old virtues and dogmas were found and dusted. Now all that restrained the free competition in the market were considered a danger to the growth and the welfare. The impact of trade unions on wage formation should be limited, the welfare state should be reduced, and 'modernised' and the incentive structure strengthened by reducing social policy standards. Unemployment was again considered a natural part of the economy where individual choices were crucial to whether you were unemployed or not: lower your wage claims and you would probably get a job.

As a part of the Maastricht Treaty in 1992, a consensus between the representatives of capital and labor had to be invented. An ideal model for European employment policy should be found to supplement the strengthening of the internal market and the canonisation of the free movement of capital, labor, goods, and services. The result was the so-called social dimension, which could act as a counter weight for the employees. The Danish labor market policy from the 1960s became the prototype of the European employment policy and was called flexicurity, and from the late 1990s until the crisis' breakout in 2008, flexicurity celebrated triumphs as a political-ideological construction for a common reference model (Larsson 1998).

\section{Flexicurity}

Flexicurity is composed of the concepts of flexibility and security where flexibility is designed to ensure companies that they can obtain, use and dispose of the workforce

\footnotetext{
${ }^{1}$ Corresponding author: Jens Lind, E-mail: jlind@socsci.aau.dk.
} 
according to their needs, and where security is to ensure labor decent living conditions during periods of unemployment and ongoing opportunity for adapting their skills to the needs of the companies. The key element of flexicurity is a high compensation in the form of social or unemployment benefits, a comprehensive training and a qualification of the workforce combined with strict availability rules and activation measures for the unemployed, and little job security in the form of short notice periods for employees.

In the 1960 s and early 1970 s, in Denmark, unemployment benefit was set as a general maximum of $90 \%$ of the average salary and with an individual maximum of $90 \%$ of previous income. The average compensation rate for a worker was in the early 1980 s about $75 \%$, but after 20 years of reductions, this compensation ratio dropped to $55 \%$ in 2005 and has since been lowered further (LO, 2006). The benefit period was during the same period reduced from in principle infinite - if the unemployed exercised their right to activation, then the right to unemployment benefits could be reearned in 6 months to 2 years in 2011. The waiting period for entitlement to benefits was in 00s raised from 6 months to 1 year of employment and, since around 1980, the availability rules were made stricter and stricter. In addition, the activation schemes for the long-term unemployed were changed from the early 1980s, where they were focused on training and helping the unemployed, to focus on increasing incentives for the unemployed to find a job: the schemes had increasingly become a disciplinary instrument.

Altogether, the cuts in unemployment legislation changed from compensation for unemployment, which was seen as result of societal structures, to increased incentives for individuals to find a job as unemployment was now seen as caused by the individual himself (Møller et al., 2008). Social security has deteriorated substantially and increasingly; since the early 1980s, periods of unemployment imply significant deterioration of living standards. When the workforce today is still very flexible, it is not because of a high degree of security, but due to a high degree of insecurity.

It has probably also been important for killing of the flexicurity model that many Danish companies have not been able or did not wish to exploit the part of flexicurity thinking which emphasizes organizational and technological progress. Rather, it looks like companies have preferred to secure profitability by means of sweating instead of implementing organizational, technical, and innovative improvements: considering the development of productivity over many years, the general trend has been a decline in productivity, and especially in recent years, productivity growth has been negative. Another indicator for low productivity is business' expenditure on research and development, as a percentage of GDP, has declined slightly since 2009 [Produktivitetskommissionen (Productivity Commission), 2014].

Employers have always argued for wage moderation and in times of crisis, even for wage cuts. Since the economic crisis of 2008 , the trade unions at the collective bargaining have been met with demands for as much moderation that in fact there have been requests for a decrease in real wage (Madsen, 2011). The alternative to such wage reductions have often been threats of mass redundancies and closures of business and work places. Instead of utilizing the flexicurity model's incentive to productivity improvements, it seems that too many Danish companies have stuck to keeping down wages. They seek to make profits not through productivity improvements and innovation but by employing more low-paid labor. 


\section{An alternative}

In contrast to wage reductions, we highlight that a relatively high wage level will be a strong incentive for companies through rationalization, capital investment, and changed organizational structures to ensure innovation and growth. It might at first glance look more like complementarities than an alternative. Rather, this represents a significant different perception of the role of the state, as we do advocate for a flexicurity model, which is both growth-promoting and creating a good security for the workers in case of unemployment. We argue for a welfare state, which emphasizes decent wages, good employment opportunities, and (almost) the abolition of unemployment.

When we argue that the former Swedish model, Folkhemsmodellen (Peoples home model) or Rehn-Meidner model, is an alternative to the paradigms and models that are dominant today, it is primarily because its stated aim is full employment and equality (Hedborg \& Meidner, 1986). Today, the main economic policy objective is low inflation, which can be achieved through effective competition - in the labor market, this means an effective competition between suppliers of labor and therefore the presence of unemployment, at a certain level. According to the Rehn-Meidner model, inflation should be curbed through concerted and responsible agreements between representatives of capital and labor, which is a modified model of competition where competition in the product market is the underlying factor for the negotiation result obtained.

The three main elements of the Rehn-Meidner model are a) a solidaristic wage policy, b) an active labor market policy, and c) a tight fiscal policy. The solidarity wage policy must ensure fair and equal distribution of incomes. When incomes (wages) shall be made equal, and partly independent of each company's economic situation, some companies will not survive. The companies that do not invest in new machinery to increase productivity will not be able to cope. The solidaristic wage policy must therefore be used to push companies to compete on productivity and not to sweating. The competitive advantage for individual companies should not be achieved through relative wage reductions but through investments.

A solidaristic wage policy (wage compression) improves employment (Barth \& Moene, 2012), but some companies may go bankrupt. Such companies should not be subsidized 'either by the government or the unions' (Elvander, 1988), but the workers who lose their jobs must receive fair compensation and offered another job, retraining, or education so that they can find employment elsewhere. This so-called 'active labor market policy' is the second cornerstone of the Rehn-Meidner model.

The third component, low inflation through a restrictive fiscal policy, shall ensure that wage demands from trade unions are kept in check and the national economy thus remains competitive.

The Swedish model was buried during the 1980s when the Swedish economy cracked. First and foremost because capital movements were freed and Swedish capital simply moved abroad. Should a similar model be established today, it requires a better regulation of capital flows and movement of labor. However, the current crisis in the EU coherence, the Brexit, and the many populist and right wing parties and movements across Europe are nourished by the social insecurity resulting from workers moving around and selling their labor at a low price. 


\section{Outline for a new unemployment system}

The capitalist system has always used unemployment to adapt the economic cycles. Unemployment is used to discipline workers to accept lower wages and poorer working conditions. But unemployment is also a waste of resources, and seen from a global economic perspective, unemployment is a waste of (human)resources. At the same time, unemployment creates economic and social insecurity and thus a lack of demand that further increases unemployment. Not least, unemployment often results in inferiority and psychological problems, and it causes some people to suspect the unemployed for being lazy. It is therefore important to avoid unemployment in society - one of the goals in the Rehn-Meidner model.

However, a goal of full employment does not mean that unemployment can be totally eliminated. It is therefore important to create a system that minimizes the unemployment rate, and at the same time improves flexibility. The means are offers and positive incentives, as opposed to negative consequences. It is formulated in the following 8 points.

1. Establish a public and regional labor counseling for everyone - unemployed, students and employees - which is voluntary and free of charge. The counseling shall focus on future employment opportunities - including retraining and further education. Trade unions and employers' associations shall participate in the counseling.

2. Priority should be given to education and new forms of education should be established, especially for educationally disadvantaged groups. All firms are put under the obligation to establish apprenticeships and traineeships for which they are financially compensated. User fees should be abolished.

3. A job bank should be established with guaranteed jobs within the public sector. The guaranteed jobs should be established within a wide range of job areas including both unskilled jobs in administrative and managerial positions within the public sector. The guaranteed jobs should consist of a wide range of areas: better staffing in nurseries, kindergartens, recreation centers, schools, and training for all categories of staff in hospitals, social counseling, rehabilitation, and a further expansion of schools and other public institutions, environmental improvements and clearing up of contaminated sites and construction of natural parks, etc. Both the state and the municipalities should be responsible for the establishment of guaranteed jobs with which they already, today, have some experience.

4. Guaranteed jobs shall be extraordinary jobs, negotiated with the social partners, and must not displace regular jobs in the public sector. To avoid displacement, a relatively fixed norm of employment must be established at public sector work places. Guaranteed jobs are jobs with normal rights and obligations, except that wages correspond to the minimum wage in the occupation.

5. Flex jobs (jobs with wage subsidies) are offered to people with all kind of disabilities, including people with lasting physical, social, and personal problems. Moreover, there should be established more social-economic jobs.

6. Unemployment insurance and unemployment fees are made compulsory for all employees, and it is financed by increasing the existing labor market taxation paid by all employed persons. 
7. Unemployment benefits can be received for a maximum of 3 months and this period is available for the unemployed persons either to obtain a job or start further training or retraining, supported by the counseling, mentioned above, cf. point 1 . Thereafter, you are offered a guaranteed job or training.

8. A UBI - unconditional basic income is established as an option for those who chose to do without a guaranteed job or training. The amount of UBI is set politically but may not be below the poverty line. The amount is allocated to each person without consideration to marital status or cohabitation relationships. There is no obligation to work and the present social assistance scheme will be abolished.

The advantages of the above outlined system are that unemployment is minimized to the maximum of 3 months for searching new jobs or training. The outline does not include coercion, and therefore not (enforced) activation. It also reduces the societal 'waste' because everybody performs work or participates in training. Moreover, the unemployed evade suspicion of laziness. The trade union movement must play a central role in the consulting and in the development of guaranteed jobs and training.

The economic consequences of this system are difficult to predict. It depends on how many persons that will replace unemployment benefits or social assistance with guaranteed jobs, training, or UBI. Today, social assistance is more or less equivalent to the poverty line income and it works as a Basic Income. While unemployment benefits are approximately $25 \%$ higher, but they are only received by insured unemployed. It is also difficult to predict the consequences for the labor force. It is difficult to foresee how many will choose UBI and guaranteed jobs.

\section{Summary and outlook}

We are aware that the alternative model presented here will encounter some 'head shaking' in a period when liberalism, market regulation, and competition are the prevailing paradigms. Conversely, the model could be criticized as being suited to the capitalist system. Also, we ourselves are dissatisfied with that the guaranteed jobs have an element of secondary or 'B-labour'-market and indeed the risk that the public sector will exploit the system by replacing regular jobs with guaranteed jobs.

The starting point of our article is that recent decades have shown a 'race to the bottom' when it comes to wages and working conditions. The highly acclaimed flexicurity model has become a 'tame duck', and insecurity in the labor market has increased. But it need not be the case.

\section{References}

Barth, E., Moene, K. O. (2012). Employment as a Price or a Prize of Equality: A Descriptive Analysis. doi: https://doi.org/10.19154/njwls.v2i2.2355.

Beskceftigelsesministeriet http://bm.dk/.

Elvander, N. (1988). Den svenske modellen, (The Swedish model), Allmena Förlaget, Stockholm. 
Hedborg, A., Meidner, R. (1984). Folkhemsmodellen, (The peoples' home model), Rabén \& Sjögren, Borås.

Madsen, P. K. (2011). Flexicurity i modvind - en analyse af den danske flexicurity-model under den økonomiske krise (Flexicurity in head wind - an analysis of the Danish flexicurity model during the economic crisis) in Tidsskrift for Arbejdsliv, 13, 4, 7-20.

Larsson, A. (1998). 'Social Policy and Economic Performance' in Foden, D. \& Morris, P.: The Search for Equity, London, pp. 24-41.

LO (2006). Dagpengesystemet. En analyse af dagpengesystemets doekning, (The unemployment benefit system. An analysis of the coverage of the unemployment benefit system), LO, København.

Møller, I. H. et al (2008). Aktivering - disciplinering til arbejde, (Activation - disciplining to work), CASA \& LEO. København.

Produktivitetskommissionen (2014). Slutrapport. Det handler om velstand og velford, (Final report. It is about affluence and welfare), København. 